\title{
Genetic diversity in passion fruit plants at different altitudes
}

\author{
Khétrin Silva Maciel ${ }^{1 *}$, Paula Aparecida Muniz de Lima², Fernando Zanotti Madalon ${ }^{3}$, Márcia Flores da \\ Silva Ferreira ${ }^{4}$, Rodrigo Sobreira Alexandre ${ }^{5}$, José Carlos Lopes ${ }^{4}$
}

\author{
${ }^{1}$ Center for Agroforestry Sciences, Federal University of Southern Bahia, (Universidade Federal do Sul da Bahia), \\ Ilhéus, BA, Brazil \\ ${ }^{2}$ Postgraduate of Plant Production, Federal University of Espírito Santo (Universidade Federal do Espírito Santo), \\ Alegre, Espírito Santo, Brazil \\ ${ }^{3}$ Postgraduate School of Agriculture "Luiz de Queiroz" University of Sao Paulo, (Escola Superior de Agricultura "Luiz \\ de Queiroz" Universidade de São Paulo), Piracicaba, SP, Brazil \\ ${ }^{4}$ Department of Plant Production, Federal University of Espírito Santo (Universidade Federal do Espírito Santo), \\ Alegre, Espírito Santo, Brazil \\ ${ }^{5}$ Department of Forest Sciences, Federal University of Espírito Santo (Universidade Federal do Espírito Santo), \\ Alegre, Espírito Santo, Brazil
}

*Corresponding author: khetrinmaciel@ufsb.edu.br

\section{Abstract}

Passion fruit belongs to the Passifloraceae family and to the genus Passiflora, which is economically relevant. This genus is originated from Brazil, which has the greatest genetic diversity. The altitudinal gradient may influence the distribution of genetic variation in and between plant populations and genetic diversity may change according to the altitude. The objective of this study was to evaluate the genetic diversity in passion fruit in different altitudes of Espírito Santo, using microsatellite markers (SSR) and inter simple sequence repeat (ISSR). Five matrixes plants of each species of Passiflora edulis Sims f. flavicarpa Degener, $P$. edulis Sims and P. alata Curtis were studied at three altitudes (low, medium and high) in the state of Espírito Santo. For each sample, 13 microsatellite markers developed for Passiflora edulis and 14 ISSR primers were amplified according to the greatest number of polymorphic fragments and amplification quality. Low values of alleles were found (1-3), and low heterozygosity was expected and slight PIC values were found, while for the ISSR analysis a large number of bands per primer were detected and high polymorphism. The $P$. alata Curtis species was the most divergent to $P$. edulis Sims f. flavicarpa Deg. and $P$. edulis Sims. The SSR and ISSR markers enabled us to indicate differences among the species, but they did not always show variation between and within similar species. The populations of low altitude are different from the others, independent of the species and the marker used. The habitat has a highly important influence on genetic diversity.

Keywords: genetic dissimilarity, heterozygous, ISSR, Passiflora spp., SSR.

Abbreviation: A_amplitude of the fragments generated by the primers; DF_degree of freedom; Fm_maximum frequency of alleles; Fst and DST_fixation index; He_expected heterozygosity; MS_mean square; NA_allele number; NBP_number of polymorphic bands; $\mathrm{Nm} \_$mean number of alleles; $\mathrm{Nr} \_$number of rare alleles; $\mathrm{Nt}$ _ total number of alleles; NTB_total number of bands; \% P_percentage of polymorphism; Pa_allele proportion in each population; PIC_polymorphic information content; SQ_sum of square; SV_source of variation.

\section{Introduction}

The genus Passiflora (family Passifloraceae) is from Brazil, which has the greatest genetic diversity with approximately 139 species (Bernacci et al., 2013). The genus is widely distributed throughout the Americas, and has a great genetic variability to be studied and used in breeding programs. The species of this genus presents economic, medicinal, ornamental, and social value (Freitas et al., 2011). The yellow passion fruit (Passiflora edulis Sims $f$. flavicarpa Degener), the purple ( $P$. edulis Sims) and the sweet ( $P$. alata Curtis) commercially stand out. Yellow passion fruit is economically more interesting (Bellon et al., 2007) due to the fruit quality, yield and consumer preference. The others are cultivated in small areas for consumption in restricted markets (Santos et al., 2011).

The most suitable regions for the planting passion fruit are those with altitudes between 100 and 1,000 m, and average temperature between 25 and 26 우; with precipitation between 1,200 and 1,400 mm, well distributed throughout the year, low relative humidity and high luminosity. The plant needs 11 hours of light / day in order to flower and produce quality fruits for flavor and aroma (Fraife Filho et al., 2010). Altitude gradients bring together a set of environmental 
variables that influence the genetic variation between and within populations and the distribution of plant species, being complex and variable between species (Ohsawa and Ide, 2008; Byars et al., 2009). The altitudinal gradient may influence the distribution of genetic variation in and between plant populations and genetic diversity may change according to the altitude.

Genetic diversity in the genus Passiflora has been studied by DNA molecular markers (Costa et al., 2012; Cerqueira Silva et al., 2014a; Cerqueira Silva et al., 2014b; Lougon et al., 2014). Between the markers, microsatellites are preferred because they are codominant and multi-allelic (Vieira et al., 2016). The occurrence of common microsatellites between Passiflora species (Castro et al., 2016) makes it possible to study the genetic diversity of different species of the genus with the same microsatellites. Therefore, this makes it possible to compare studies between species (Barbará et al., 2007). This maker is highly polymorphic in a intraspecific level, but it kept the locus conserved between close species, thus being necessary to compare the intraspecific discrimination level. One way to compare them is using neutral markers by distributing them in the genome, such as the inter simple sequence repeat (ISSR), which are dominant and very important in studies of interspecific genetic diversity (Santos et al., 2011) and intraspecific passion fruit (Melo et al., 2016).

The objective of this study was to evaluate the genetic diversity in passion fruit in different altitudes of Espírito Santo using the microsatellite markers (SSR) and inter simple sequence repeat (ISSR).

\section{Results}

\section{Polymorphism screening of SSR loci}

One to three alleles were detected by microsatellite locus in the three Passiflora species (Table 3), totaling 29 alleles in $P$. edulis Sims; 28 in P. edulis Sims f. flavicarpa Deg. and 24 in $P$. alata. Fixed alleles were found in the three species, but appeared more frequently in $P$. alata $(78.6 \%)$, which also had the lowest values of expected heterozygosity, PIC and number of average alleles.

The highest values of expected heterozygosity and PIC were obtained for the locus PE 15 ( $\mathrm{He}=0.611$; PIC $=0.535)$ in $P$. edulis Sims f. flavicarpa Deg., $\mathrm{PE} 18(\mathrm{He}=0.631 ; \mathrm{PIC}=0.556)$ in P. edulis Sims and P. Alata Curtis ( $\mathrm{He}=0.650 ; \mathrm{PIC}=0.575)$. Most of the locus presented a maximum frequency parameter $(\mathrm{mf})$ of alleles greater than $50 \%$, indicating higher frequency of few alleles in the locus genotypes. Only the PE 08 and PE 18 locus in P. edulis Sims and PE 18 in P. alata Curtis had this parameter below $50 \%$ (Table 3 ).

Passiflora edulis Sims had a higher mean allele number (2.23), higher total allele number (29) and highest allele proportion in each population (0.73). Passiflora edulis Sims and $P$. alata Curtis presented a rare allele, each with 3.45 and $4.17 \%$, respectively (Table 4 ).

\section{Polymorphism screening of ISSR loci}

The ISSR analysis detected a large number of bands per primer and a low percentage of monomorphic markers, therefore suggesting high interspecific genetic variability of the accessions. From the 14 ISSR markers evaluated in the
Passiflora spp. species, 178 bands were observed, ranging in size between 110-2,200 bp, mean of 12.71 bands per primer, of which $96 \%$ were polymorphic. The ISSR markers, 854,865 , 878 and 886 , presented a large number of bands (16) and 887 and 890 presented a small number of bands (9). All species showed a high number of polymorphic bands ranging from $94 \%$ for P.alata, $97 \%$ for $P$. edulis sims $f$. flavicarpa Deg. and $98 \%$ for $P$. edulis Sims (Table 5).

\section{AMOVA}

The analysis of molecular variance (AMOVA) of the Passiflora species for both markers showed significant differences in the three species between and within populations, as well as between altitudes. The Fst values were higher for SSR data and $P$. alata Curtis presented the highest Fst value (0.81) with this marker. The Fst presented a higher value for the SSR data, in relation to the ISSR for the three altitudes. The highest value of Fst (0.87) was observed at a low altitude for SSR (Table 6).

There was a higher genetic difference in each species according to the altitude at which it was collected, and it was observed due to high genetic variation between altitudes for each species with SSR data. $P$. edulis Sims presented similar results with the use of both markers. However, for $P$. edulis Sims f. flavicarpa Deg. there was no significant variation within the altitudes, and for the $P$. alata Curtis species there was a higher variation within and between the altitudes, by the analysis with ISSR (Table 6).

The three species were studied together in each of the three altitudes (Table 6). High variation between species was observed by the SSR data, different from those obtained with ISSR, which revealed a higher difference within the species in a high altitude (62.85\%) and medium altitude $(62.95 \%)$. For the low altitude, with the ISSR data, the genetic diversity within (48.72) and among (51.28) the altitude was similar.

\section{Clustering}

Corroborating the variation data between and within the two markers, the clusters showed greater interpopulation genetic, similar to SSR and intrapopulation, with ISSR data (Figure 2). The population in low altitude differed from the others, regardless of the species and the marker used, and the medium and high altitude populations did not distinguish with SSR markers, but with ISSR markers.

The species $P$. alata Curtis showed a clear distinction between the individuals, depending on the altitude, and independent of the marker, with a formation of three well defined groups. The highest and the lowest genetic distances were between 0.46 and 0.05 , respectively with SSR, and 0.70 and 0.26 , respectively for ISSR (Figure $2 \mathrm{C}$ ).

Passiflora edulis Sims f. flavicarpa Deg. presented higher $(0.75)$ and lower $(0.11)$ genetic distances between SSR data accessions. The individuals at low altitude presented higher genetic dissimilarity in relation to the others and higher genetic similarity between them. With ISSR, (the highest and lowest dissimilarities between indivdiuals were 0.77 and 0.45 , respectively), and three groups were formed (Figure 2 A).

For $P$. edulis Sims. smaller and larger genetic distances between the 15 accessions, by SSR were 0.66 and 0.07 , 
Table 1. Place of collection of the plants of the species of Passiflora spp.

\begin{tabular}{|c|c|c|c|c|}
\hline Species & Locality & Latitude (South) & Longitude (West) & Altitude $(\mathrm{m})$ \\
\hline \multirow{3}{*}{$\begin{array}{l}\text { P. edulis Sims } \mathrm{f} \text {. } \\
\text { flavicarpa Degener }\end{array}$} & Santa Maria de Jetibá & 19o 59' $37,68^{\prime \prime}$ & 40 - 40' $25,68^{\prime \prime}$ & 674 \\
\hline & Alegre & $20046^{\prime} 13,06^{\prime \prime}$ & 41 o $30^{\prime} 27,96$ " & 365 \\
\hline & Marataízes & $21009^{\prime} 32,58^{\prime \prime}$ & 40 인 $07,56^{\prime \prime}$ & 6 \\
\hline \multirow{3}{*}{ P. edulis Sims } & Santa Maria de Jetibá & 19o 59'40,32" & 40 - 40' $21,66^{\prime \prime}$ & 674 \\
\hline & Jerônimo Monteiro & $20047^{\prime} 43,86^{\prime \prime}$ & $41^{\circ} 30^{\prime} 33,96^{\prime \prime}$ & 210 \\
\hline & Marataízes & $21009^{\prime} 32,28^{\prime \prime}$ & $40 \circ 55^{\prime} 07,62^{\prime \prime}$ & 6 \\
\hline \multirow{3}{*}{ P. alata Curtis } & Santa Maria de Jetibá & $20002^{\prime} 34,20^{\prime \prime}$ & 40 - 43' 34,08" & 655 \\
\hline & Alegre & $20047^{\prime} 44,94^{\prime \prime}$ & $41^{\circ} 30^{\prime} 35,52^{\prime \prime}$ & 350 \\
\hline & Jerônimo Monteiro & $20 \cong 46^{\prime} 13,06^{\prime \prime}$ & $41025^{\prime} 33,06^{\prime \prime}$ & 100 \\
\hline
\end{tabular}

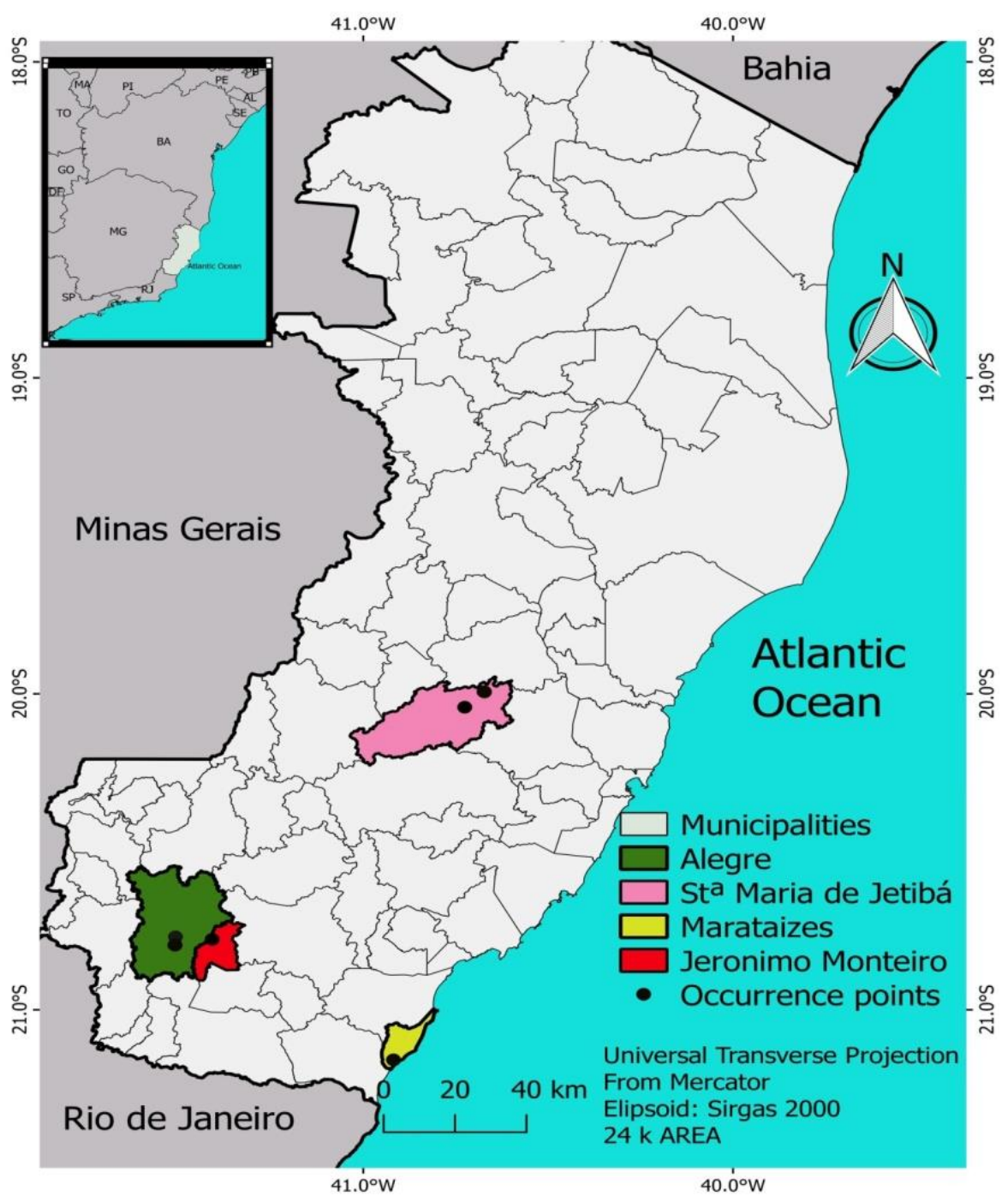

Fig 1. Passiflora spp sampling locations in the state of Espírito Santo, Brazil. The circles indicate the sampled localities: Alegre, Santa Maria de Jetibá, Marataízes e Jerônimo Monteiro. 
Table 2. SSR and ISSR markers used in the amplification of Passiflora edulis Sims f. flavicarpa Degener, P. edulis Sims and $P$. alata Curtis collected at different altitudes.

\begin{tabular}{|c|c|c|c|c|c|}
\hline $\mathrm{SSR}^{* *}$ & $\begin{array}{l}\mathrm{Ta} \\
\left({ }^{\circ} \mathrm{C}\right)\end{array}$ & Primer "foward" (5 '- 3') & Primer "reverse" (5 '- 3') & ISSR & Sequence $5^{\prime} \rightarrow 3^{\prime}$ \\
\hline PE03 & 60 & GCAGCGAGGGAAGAAAAA & TGAGACATCGTGCGTGAA & UBC 807 & AGAGAGAGAGAGAGAGT \\
\hline PE08 & 56 & CCGGATACCCACGCATTA & TCTAATGAGCGGAGGAAAGC & UBC 808 & AGAGAGAGAGAG AGAGC \\
\hline PE15 & 56 & ACCGTTAAATCCAAGCAAGT & AAATGCAAAGAATGATATGTTA & UBC 810 & GAGAGAGAGAGAGAGAT \\
\hline PE18 & 56 & CCGTGAACCAACCATTTCTC & CCGTGAACCAACCATTTCTC & UBC 811 & GAGAGAGAGAGAGAGAC \\
\hline PE20 & 58 & AGGATCACCATAGAAAACCAT & GTTAGGTTGGCATTGCTCTT & UBC 812 & GAGAGAGAGAGAGAGAA \\
\hline PE23 & 60 & CAATCCCTTGACCCATAGA & CGTCCATCCTTCTCCTTT & UBC 815 & 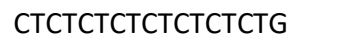 \\
\hline PE27 & 58 & TTGCTCATTGCACTCATCCT & GCAGACATTTCCTGGAGCA & UBC 842 & GAGAGAGAGAGAGAGAYG \\
\hline PE37 & 60 & CAAAAGGATAGGCCTGATGTC & TGCTTGGTCATCCACTGAAG & UBC 854 & TCTCTCTCTCTCTCTCRG \\
\hline PE38 & 60 & GATCGGTCCTCGGTTAGAC & AGTCACACAGCATGAGAAATC & UBC 865 & CCGCCGCCGCCGCCGCCG \\
\hline PE41 & 56 & ATCGGGGTTCGCTTATTTG & CGTTCATCCTTTAGTGGGCTA & UBC 878 & GGATGGATGGATGGA \\
\hline PE66 & 60 & CCATAGTCCCAACAAGCATC & GCTGTGGACCCTAACTCAGTC & UBC 886 & VDVCTCTCTCTCTCTCT \\
\hline PE74 & 60 & СССТCTTATCAATAGCGTTGG & GCACGAGCACGAGTATTTATT & UBC 887 & DVDTCTCTCTCTCTCTC \\
\hline \multirow[t]{2}{*}{ PE90 } & 60 & TCAGGAAGATTGCATGTTAGT & CTGGGTTTTGTTTATGTTGC & UBC 890 & VHVGTGTGTGTGTGTGT \\
\hline & & & & UBC 891 & HVHTGTGTGTGTGTGTG \\
\hline
\end{tabular}

"*Oliveira et al. (2006).

perature in degrees Celsius.

IUB nomenclature for degenerate bases " $V$ " $=A+C+G$; " $D$ " = A+T+G; " $H$ " = A+C+T

Table 3. Characterization of 13 SSRs used in the molecular characterization of Passiflora spp.

\begin{tabular}{|c|c|c|c|c|c|c|c|c|c|c|c|c|c|c|c|c|}
\hline \multirow{2}{*}{ SSR } & \multicolumn{4}{|c|}{ Total } & \multicolumn{4}{|c|}{ P. edulis Sims f. flavicarpa Degener } & \multicolumn{4}{|c|}{ P. edulis Sims } & \multicolumn{4}{|c|}{ P. alata Curtis } \\
\hline & $\mathrm{He}$ & PIC & NA & $\mathrm{fm}$ & $\mathrm{He}$ & $\mathrm{PIC}$ & NA & $f m$ & $\mathrm{He}$ & PIC & NA & $f m$ & $\mathrm{He}$ & $\mathrm{PIC}$ & NA & $f m$ \\
\hline PE03 & 0.092 & 0.079 & 1 & 0.944 & 0.000 & 0.000 & 1 & 1.000 & 0.000 & 0.000 & 1 & 1.000 & 0.277 & 0.239 & 2 & 0.833 \\
\hline PE08 & 0.535 & 0.436 & 2 & 0.532 & 0.540 & 0.452 & 3 & 0.571 & 0.578 & 0.486 & 3 & 0.454 & 0.489 & 0.369 & 2 & 0.571 \\
\hline PE15 & 0.567 & 0.494 & 3 & 0.555 & 0.611 & 0.535 & 3 & 0.500 & 0.480 & 0.412 & 3 & 0.666 & 0.611 & 0.535 & 3 & 0.500 \\
\hline PE18 & 0.570 & 0.489 & 2 & 0.512 & 0.429 & 0.337 & 2 & 0.687 & 0.631 & 0.556 & 3 & 0.466 & 0.650 & 0.575 & 3 & 0.384 \\
\hline PE20 & 0.000 & 0.000 & 1 & 1.000 & 0.000 & 0.000 & 1 & 1.000 & 0.000 & 0.000 & 1 & 1.000 & 0.000 & 0.000 & 1 & 1.000 \\
\hline PE23 & 0.263 & 0.210 & 1 & 0.819 & 0.375 & 0.304 & 2 & 0.750 & 0.413 & 0.327 & 2 & 0.708 & 0.000 & 0.000 & 1 & 1.000 \\
\hline PE27 & 0.310 & 0.254 & 2 & 0.786 & 0.152 & 0.141 & 2 & 0.916 & 0.459 & 0.353 & 2 & 0.642 & 0.320 & 0.268 & 2 & 0.800 \\
\hline PE37 & 0.083 & 0.077 & 1 & 0.955 & 0.124 & 0.116 & 2 & 0.933 & 0.124 & 0.116 & 2 & 0.933 & 0.000 & 0.000 & 1 & 1.000 \\
\hline PE38 & 0.083 & 0.077 & 1 & 0.955 & 0.124 & 0.116 & 2 & 0.933 & 0.124 & 0.116 & 2 & 0.933 & 0.000 & 0.000 & 1 & 1.000 \\
\hline PE41 & 0.499 & 0.430 & 2 & 0.648 & 0.544 & 0.483 & 3 & 0.615 & 0.544 & 0.483 & 3 & 0.615 & 0.408 & 0.324 & 2 & 0.714 \\
\hline PE66 & 0.534 & 0.426 & 2 & 0.511 & 0.606 & 0.529 & 3 & 0.500 & 0.500 & 0.375 & 2 & 0.500 & 0.497 & 0.373 & 2 & 0.533 \\
\hline PE74 & 0.131 & 0.119 & 2 & 0.926 & 0.244 & 0.214 & 2 & 0.857 & 0.074 & 0.071 & 2 & 0.961 & 0.074 & 0.071 & 2 & 0.961 \\
\hline PE90 & 0.325 & 0.277 & 2 & 0.776 & 0.320 & 0.268 & 2 & 0.800 & 0.524 & 0.440 & 3 & 0.600 & 0.132 & 0.123 & 2 & 0.928 \\
\hline Mean & 0.307 & 0.259 & 1.69 & 0.763 & 0.313 & 0.269 & 2.15 & 0.774 & 0.342 & 0.287 & 2.23 & 0.729 & 0.266 & 0.221 & 1.85 & 0.786 \\
\hline
\end{tabular}

Mean $0.307 \quad 0.259 \quad 1.69 \quad 0.763 \quad 0.313 \quad 0.269 \quad 2.15$ lates. 


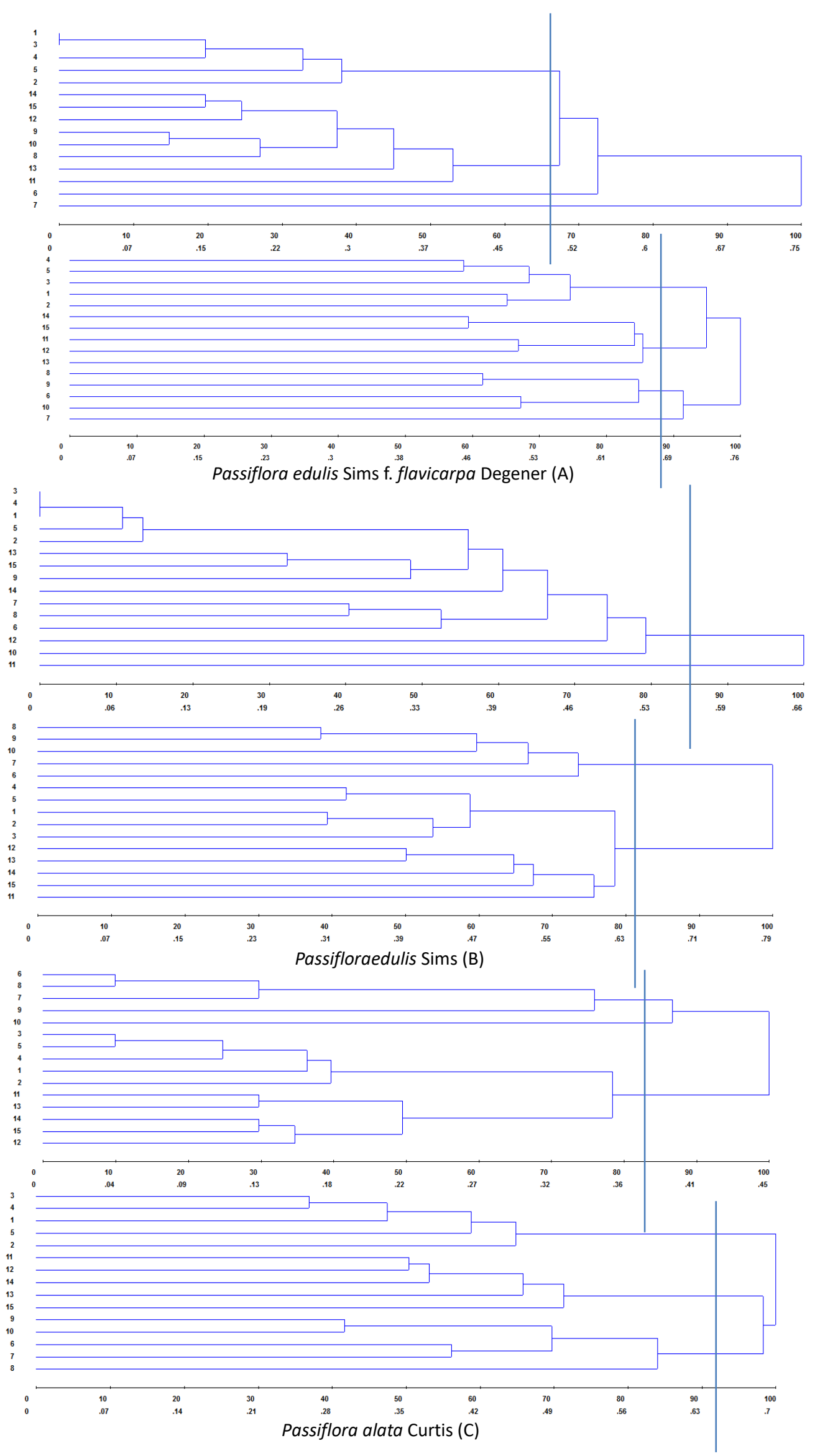

SSR

Fig 2. Dendrogram of the species of Passiflora spp., ( 5 individuals of each species at 3 altitudes) obtained by the UPGMA method. Legend: $1,2,3,4,5=$ low altitude, $6,7,8,9,10=$ average altitude, $11,12,13,14,15=$ high altitude. 


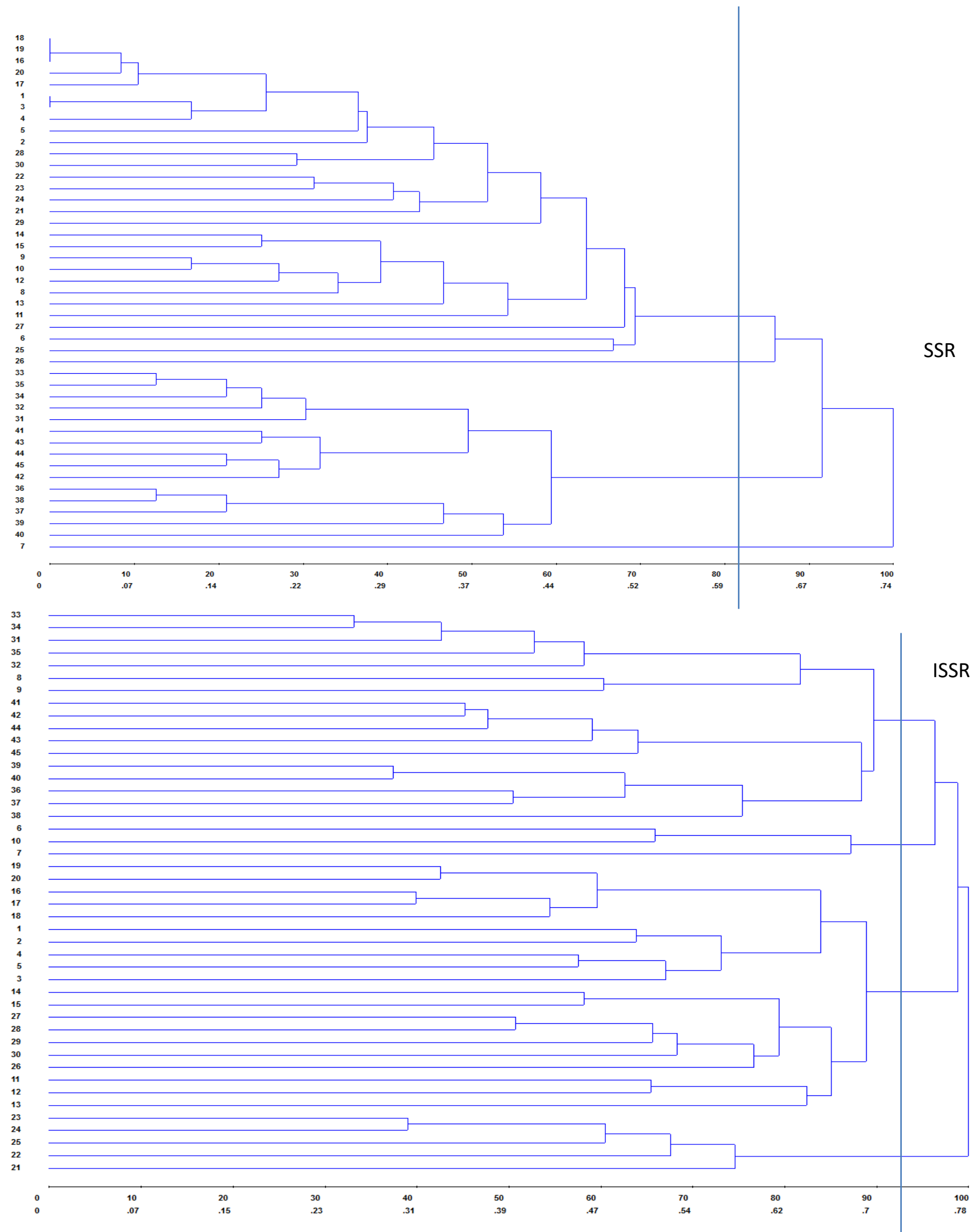

Fig 3. Grouping of individuals belonging to the three species of Passiflora spp. (5 individuals of each species at 3 altitudes), obtained by the UPGMA method. 
Table 4. Mean number (Nm), total (Nt) of alleles, allele proportion in each population (Pa) and number of rare alleles (Nr) for SSR.

\begin{tabular}{lllll}
\hline Species & $\mathrm{Nm}$ & $\mathrm{Nt}$ & $\mathrm{Pa}$ & $\mathrm{Nr}(\%)$ \\
\hline Passiflora edulis Sims f. flavicarpa Degener & 2.15 & 28 & 0.70 & 0.00 \\
Passiflora edulis Sims & 2.23 & 29 & 0.73 & 3.45 \\
Passiflora alata Curtis & 1.85 & 24 & 0.60 & 4.17 \\
\hline
\end{tabular}

Table 5. Analysis of the ISSR primers of Passiflora spp.

\begin{tabular}{|c|c|c|c|c|c|c|c|c|c|c|c|c|c|c|c|c|}
\hline \multirow[t]{2}{*}{ ISSR } & \multicolumn{4}{|c|}{ Total } & \multicolumn{4}{|c|}{$\begin{array}{l}\text { P. edulis Sims f. flavicarpa } \\
\text { Degener }\end{array}$} & \multicolumn{4}{|c|}{ P. edulis Sims } & \multicolumn{4}{|c|}{ P. alata Curtis } \\
\hline & NTB & NBP & $\% \mathrm{P}$ & $A$ & NTB & NBP & $\% \mathrm{P}$ & A & NTB & NBP & $\% \mathrm{P}$ & V & NTB & NBP & $\% \mathrm{P}$ & $A$ \\
\hline UBC 807 & 12 & 12 & 100 & $1500-370$ & 14 & 14 & 100 & $1500-370$ & 13 & 13 & 100 & $1000-370$ & 11 & 11 & 100 & $900-370$ \\
\hline UBC 808 & 10 & 10 & 100 & $1050-380$ & 12 & 12 & 100 & $1010-390$ & 12 & 12 & 100 & $1050-380$ & 8 & 8 & 100 & $1010-490$ \\
\hline UBC 810 & 14 & 11 & 78 & $1000-110$ & 18 & 14 & 78 & $1000-110$ & 10 & 9 & 90 & $900-110$ & 15 & 10 & 67 & $1000-150$ \\
\hline UBC 811 & 12 & 11 & 92 & $1500-290$ & 11 & 10 & 91 & $1500-390$ & 12 & 12 & 100 & $1500-490$ & 14 & 12 & 86 & $1300-290$ \\
\hline UBC 812 & 10 & 10 & 100 & $1200-350$ & 10 & 10 & 100 & $1200-350$ & 9 & 9 & 100 & $850-350$ & 11 & 11 & 100 & $1200-350$ \\
\hline UBC 815 & 13 & 13 & 100 & $1100-300$ & 14 & 14 & 100 & $1100-300$ & 16 & 16 & 100 & $1100-300$ & 10 & 10 & 100 & $1050-380$ \\
\hline UBC 842 & 13 & 13 & 100 & $750-250$ & & 15 & 100 & $750-250$ & 13 & 13 & 100 & $750-250$ & 13 & 13 & 100 & $750-250$ \\
\hline UBC 854 & 16 & 16 & 100 & $2000-290$ & 16 & 16 & 100 & $1800-290$ & 18 & 18 & 100 & $2000-290$ & 16 & 16 & 100 & $750-390$ \\
\hline UBC 865 & 16 & 16 & 98 & $1900-310$ & 19 & 19 & 100 & $1800-390$ & 13 & 13 & 100 & $1500-310$ & 18 & 17 & 94 & $1900-410$ \\
\hline UBC 878 & 16 & 16 & 100 & $2000-390$ & 17 & 17 & 100 & $2000-500$ & 15 & 15 & 100 & $1800-390$ & 17 & 17 & 100 & $2000-390$ \\
\hline UBC 886 & 16 & 15 & 98 & $2200-280$ & 18 & 18 & 100 & $2200-300$ & 13 & 13 & 100 & $1000-300$ & 17 & 16 & 94 & $2100-280$ \\
\hline UBC 887 & 9 & 9 & 100 & $1080-480$ & 9 & 9 & 100 & $1020-480$ & 9 & 9 & 100 & $1050-500$ & 9 & 9 & 100 & $1080-480$ \\
\hline UBC 890 & 9 & 9 & 100 & $1100-380$ & 11 & 11 & 100 & $1100-380$ & 9 & 9 & 100 & $1000-450$ & 7 & 7 & 100 & $1050-380$ \\
\hline UBC 891 & 12 & 10 & 86 & $1100-300$ & 13 & 12 & 92 & $1100-300$ & 12 & 9 & 75 & $1000-300$ & 12 & 11 & 92 & $1050-300$ \\
\hline Total & 178 & 171 & 96 & - & 197 & 191 & 97 & - & 174 & 170 & 98 & - & 178 & 168 & 94 & - \\
\hline
\end{tabular}

Legend: NTB = total number of bands; NBP = number of polymorphic bands; \% $\mathrm{P}=$ percentage of polymorphism; $\mathrm{A}=$ amplitude of the fragments generated by the primers.

respectively, forming two groups, one with low altitude individuals and the other with high and medium altitude individuals. Individuals at low altitude presented higher genetic dissimilarity in relation to high and medium altitude. With ISSR data, the highest and lowest genetic distances were 0.79 and 0.30 , respectively, and and three groups were formed corresponding to the different altitudes, reflecting higher genetic dissimilarity between them (Figure $2 \mathrm{~B}$ ).

Considering a general analysis of all the studied individuals of the three species, SSR data showed a higher interpopulation genetic similarity and ISSR data showed intrapopulational genetic similarity (Figure 3 ).

For the SSR data, (the smallest and largest genetic distances between the 45 accessions of Passiflora spp. were 0.67 and 0.06 , respectively), two groups were formed: one grouping $P$. edulis Sims f. flavicarpa Deg. and $P$. edulis Sims at three altitudes and another grouping $P$. alata Curtis at three altitudes. Individuals of $P$. edulis Sims f. flavicarpa Deg. and $P$. edulis Sims presented higher genetic similarity at low altitude. Individuals $1 ; 3$ and 4 ( $P$. edulis Sims at low altitude) presented $100 \%$ similarity, as well as individuals 1 and 3 ( $P$. edulis Sims f. flavicarpa Deg. at low altitude). Individuals of $P$. edulis Sims f. flavicarpa Deg. And P. edulis Sims in medium and high altitudes were grouped (Figure 3).

In the ISSR cluster analysis, (the highest and lowest genetic distances between the 45 accessions of Passiflora spp. were 0.78 and 0.26 , respectively). There were three groups: I: $P$. alata Curtis at three different altitudes, together with $P$. edulis Sims f. flavicarpa Deg. in average altitude; II: $P$. edulis Sims f. flavicarpa Deg. and P. edulis Sims in high and low altitude and III: $P$. edulis Sims in average altitude. The individuals of $P$. alata were grouped in relation to the altitudes. Individuals of $P$. edulis Sims f. flavicarpa Deg. And $P$. edulis Sims were closer at lower altitude, as were the individuals at higher altitude. However, $P$. edulis Sims in medium altitude showed higher genetic dissimilarity (Figure 3).

\section{Discussion}

The descriptive analysis of the SSR locus for expected heterozygosity in the three Passiflora spp. species presented low genetic variability in $P$. edulis Sims f. flavicarpa Deg. (He $=0,313), P$. edulis Sims $(\mathrm{He}=0.342)$ and $P$. alata Curtis $(\mathrm{He}=$ 0.266 ) locus and in general $\mathrm{He}=0.307$. Cerqueira-Silva et al. (2012), when evaluating $P$. cincinnata accessions found $(\mathrm{He}=$ $0.510)$, and Padua et al. (2005) found $(\mathrm{He}=0.520)$ in P. alata accessions. Reis et al. (2011) when studying populations of two cycles of recurrent selection in $P$. edulis obtained $\mathrm{He}=$ 0.200 . The low molecular variability can be attributed to the loss and fixation of the alleles by the selecting agronomically favorable genotypes. The variability found in the genus may be associated with the allogamy and self-incompatibility of the species (Pérez-Almeida et al., 2010). Genetic diversity in plants is influenced by the breeding system, seed dispersal, genetic drift and evolutionary history. The habitat has a highly important influence on genetic diversity ( $\mathrm{Hu}$ et al., 2014).

Regarding the polymorphic information content (PIC), Botstein et al. (1980) defined this parameter as highly informative (PIC greater than 0.5); reasonably informative (PIC between 0.25 and 0.50 ); and slightly informative (PIC values less than 0.24). 
Table 6. Analysis of molecular variance (AMOVA) of three species of Passiflora spp. collected at three altitudes, from SSR and ISSR data.

\begin{tabular}{|c|c|c|c|c|c|c|c|c|c|c|c|c|c|}
\hline & & SSR & & & & & ISSR & & & & & & \\
\hline SV & DF & SQ & MS & $\begin{array}{l}\text { Variance } \\
\text { component }\end{array}$ & $\%$ & Fst & SV & DF & SQ & MS & $\begin{array}{l}\text { Variance } \\
\text { component }\end{array}$ & $\%$ & ФST \\
\hline \multicolumn{14}{|c|}{ Passiflora edulis Sims f. flavicarpa Degener } \\
\hline Among & 2 & 6.14 & 3.07 & 0.57 & $70.26^{* *}$ & $0.70^{* *}$ & Among & 2 & 159.00 & 79.50 & 10.61 & $28.63^{* *}$ & $0.28^{* *}$ \\
\hline Within & 12 & 2.88 & 0.24 & 0.24 & $29.74^{* *}$ & & Within & 12 & 317.40 & 26.45 & 26.46 & $71.37^{\text {ns }}$ & \\
\hline Total & 14 & 9.02 & 0.64 & 0.81 & 100.00 & & Total & 14 & 476.40 & 34.03 & 37.06 & 100.00 & \\
\hline \multicolumn{14}{|c|}{ Passiflora edulis Sims } \\
\hline Among & 2 & 3.13 & 1.56 & 0.25 & $43.33^{* *}$ & $0.43^{* *}$ & Among & 2 & 188.40 & 94.20 & 15,04 & $44.21^{* *}$ & $0.44^{* *}$ \\
\hline Within & 12 & 3.89 & 0.32 & 0.32 & $56.67^{* *}$ & & Within & 12 & 227.80 & 18.90 & 18.90 & $55.79^{* *}$ & \\
\hline Total & 14 & 7.02 & 0.50 & 0.57 & 100.00 & & Total & 14 & 416.20 & 29.72 & 34.03 & 100.00 & \\
\hline \multicolumn{14}{|c|}{ Passiflora alata Curtis } \\
\hline Among & 2 & 4.53 & 2.26 & 0.43 & $80.65^{* *}$ & $0.81^{* *}$ & Among & 2 & 207.20 & 103.60 & 16.70 & $45.38^{* *}$ & $0.45^{* *}$ \\
\hline Within & 12 & 1.24 & 0.10 & 0.10 & $19.35^{* *}$ & & Within & 12 & 241.20 & 20.10 & 20.10 & $54.62^{* *}$ & \\
\hline Total & 14 & 5.77 & 0.41 & 0.53 & 100.00 & & Total & 14 & 448.40 & 32.03 & 36.80 & 100.00 & \\
\hline \multicolumn{14}{|c|}{ High Altitude } \\
\hline Among & 2 & 9.86 & 4.93 & 0.94 & $81.31^{* *}$ & $0.81^{* *}$ & Among & 2 & 165.87 & 82.93 & 12.39 & $37.15^{* *}$ & $0.37^{* *}$ \\
\hline Within & 12 & 2.60 & 0.22 & 0.22 & $18.69^{* *}$ & & Within & 12 & 251.60 & 20.97 & 20.97 & $62.85^{* *}$ & \\
\hline Total & 14 & 12.46 & 0.89 & 1.16 & 100.00 & & Total & 14 & 417.47 & 29.82 & 33.36 & 100.00 & \\
\hline \multicolumn{14}{|c|}{ Average Altitude } \\
\hline Among & 2 & 10.12 & 5.06 & 0.94 & $71.34^{* *}$ & $0.71^{* *}$ & Among & 2 & 200.80 & 100.40 & 14.99 & $37.05^{* *}$ & $0.37^{* *}$ \\
\hline Within & 12 & 4.52 & 0.38 & 0.38 & $28.66^{* *}$ & & Within & 12 & 305.60 & 25.47 & 25.47 & $62.95^{* *}$ & \\
\hline Total & 14 & 14.64 & 1.05 & 1.31 & 100.00 & & Total & 14 & 506.40 & 36.17 & 40.45 & 100.00 & \\
\hline \multicolumn{14}{|c|}{ Low Altitude } \\
\hline Among & 2 & 7.40 & 3.70 & 0.72 & $87.66^{* *}$ & $0.87^{* *}$ & Among & 2 & 239.20 & 119.60 & 20.10 & $51.28^{* *}$ & $0.51^{* *}$ \\
\hline Within & 12 & 1.22 & 0.10 & 0.10 & $12.34^{* *}$ & & Within & 12 & 229.20 & 19.10 & 19.10 & $48.72^{* *}$ & \\
\hline Total & 14 & 8.62 & 0.62 & 0.82 & 100.00 & & Total & 14 & 468.40 & 33.45 & 39.20 & 100.00 & \\
\hline
\end{tabular}

${ }^{n s}$ not significant; ${ }^{* *}$ significant at $1 \%$ probability by the $\mathrm{F}$ test, respectively.

Legend: $\mathrm{SV}=$ source of variation, $\mathrm{DF}=$ degree of freedom, $\mathrm{SQ}=$ sum of square, $\mathrm{MS}=$ mean square, Fst and ФST = fixation index

The PE 18 locus in P. alata Curtis and P. edulis Sims and PE 15 in $P$. edulis Sims f. flavicarpa Deg. were highly informative (PIC: $0.575,0.556$ and 0.535 , respectively). Overall, SSRs were classified as reasonably slightly informative for all species. Higher PIC values are related to the distribution and balance of allelic frequencies in the population in which the selected markers are reliable to detect genetic diversity (Missio et al., 2010).

In the three analyzed species, 22 alleles were found for the 13 SSR markers, ranging from 1 to 3 per locus. Paiva et al. (2014), when characterizing SSR locus, found 41 alleles, ranging from 2 to 5 alleles, with a mean of 3.42. Similar allelic variation was found by Cazé et al. (2012) with SSR locus, finding 42 alleles per locus and a variation from 2 to 9 , with an average of 5 . This shows a low number of alleles per locus and few polymorphic microsatellites have shown characteristic of this genus, therefore suggesting conserving the locus and small mutation rate (Cerqueira-Silva et al., 2014a).

Rare alleles are those with a frequency less than 0.05. The alleles are no longer rare in the population $P$. edulis Sims $f$. flavicarpa Deg., due to the increase of its frequency. Studies have reported that rare alleles may be linked to genes of agronomic interest (Reis et al., 2011).

PE03 and PE20 locus in Passiflora edulis Sims f. flavicarpa Deg and P. edulis Sims, and PE20, PE23, PE37 and PE38 in $P$. alata Curtis concentrated $1 \%$ of the maximum allele frequency. These frequencies explain the lower PIC values, and suggesting that the locus generate the lowest information content in the analyzed accessions in this study and lower genetic diversity and frequency of alleles.

In the ISSR analysis, there was a high number of bands per primer and a low percentage of monomorphic markers, thus suggesting high interspecific genetic variability of the accessions. In other studies with Passiflora, similarly high levels of polymorphism were observed with this marker, varying 70.5-98\% (Santos et al., 2011; Costa et al., 2012).

The AMOVA in each species revealed that the greatest genetic diversity occurred within and not between populations in the ISSR marker and similar results were found for Passiflora setacea (Pereira et al., 2015). These data suggest high genetic variability within plant populations, which may be due to sexual reproduction, somatic cell mutation, selection, genetic flow, genetic drift, and environmental change (Gao and Yang, 2006). The analyzed populations of each species are genetically structured by ФST values above 0.25 and they are considered indicators of a high level of structure population (Matioli, 2001).

In general, ISSR marker may be a valuable tool for studying intraspecific genetic diversity in Passiflora, mainly by grouping accessions according to genetic origin (Costa et al., 2012).

$P$. edulis Sims f. flavicarpa Deg. and $P$. edulis Sims individuals located in the middle and high altitudes were closer, and presented higher genetic similarity. Populations tend to cluster when they are geographically restricted and close (Hou and Lou, 2011). 
The results showed that $P$. alata Curtis presented higher genetic dissimilarity in relation to the other species. Larger genetic distances between $P$. edulis Sims f. flavicarpa Deg. and $P$. alata Curtis were also observed by Castro et al. (2011). Populations in low altitude differed from the others. Geographic distribution may affect the level of genetic diversity of/in a species, and species in general may have a higher level of genetic variability than those distributed in a isolated way (Hamrick and Godt, 1996). The genetic variability found in this study can be explained by the geographic difference evaluated by passion fruit accessions, pollen flow between the different genotypes and the introduction of materials from other sites by farmers. Genetic polymorphism may be associated with the nature of the allogeneic species, which tends to favor the conservation of a high percentage of heterozygous genotypes (BernalParra et al., 2014). The genus Passiflora spp. has variable agronomic characteristics, in which environmental influences are largely responsible for the changes in passion fruit.

In medium altitudes, related to high and low altitudes, there was genetic diversity in Poa hiemata (Byars et al., 2009). The diversity loss in low and high altitude populations can be due to being geographically isolated from the middle part, therefore, with reduced gene flow and genetic drift (Ohsawa et al., 2007).

The results contribute to the knowledge of inter and intraspecific variation of the analyzed species and can be used in breeding and conservation programs.

\section{Material and methods}

\section{Plant materials}

Plant samples collected in the field were composed of young leaves of plants of natural occurrence in different localities, in three altitudes ( 0 to 100 - low, $>100$ to 600 - medium and> $600 \mathrm{~m}$ - high) in the state of Espirito Santo (Figure 1) (Table 1). From each site, five matrix plants of the Passiflora edulis Sims $f$. flavicarpa Degener (yellow passion fruit) species, $P$. edulis Sims (purple passion fruit) and $P$. alata Curtis (sweet passion fruit) were sampled.

\section{Genotyping}

Genomic DNA was obtained from about $300 \mathrm{mg}$ of healthy young plant leaf tissue macerated in liquid nitrogen according to the Doyle and Doyle (1990) protocol. DNA integrity was verified in $0.8 \%$ agarose gel, stained with ethidium bromide and the concentration was determined in a spectrophotometer. DNA quality was established by the absorbance ratio A260/A280.

For each sample, 13 microsatellite markers developed for Passiflora edulis (Oliveira, 2006) were amplified (Table 2). The PCR amplification reaction consisted of: $30 \mathrm{ng}$ of DNA; $0.1 \mu \mathrm{M}$ of the primers; $1 \mathrm{U}$ of Taq DNA Polymerase; $0.2 \mathrm{mM}$ of dNTP; $1.5 \mathrm{mM}$ of magnesium chloride and I0 PCR buffer (1X - Phoneutria) in $15 \mu \mathrm{l}$ reaction. The amplification program used was 4 minutes at $94 \stackrel{\circ}{\circ}$, followed by 35 cycles; at $94{ }^{\circ} \mathrm{C}$ for 1 minute; $56-60{ }^{\circ} \mathrm{C}$ (depending on the first Table 2) for 1 minute; $72^{\circ} \mathrm{C}$ for 3 minutes, and a final extension at $72{ }^{\circ} \mathrm{C}$ for 7 minutes. The amplified fragments were separated in $6 \%$ polyacrylamide gel, with running TAE buffer (tris-base, acetic acid and EDTA), at 90 volts for approximately 3.5 hours, stained with ethidium bromide and subjected to UV light in order to be visualized.

For the amplifications with the ISSR, 14 primers were chosen (Table 2), according to the largest number of polymorphic fragments and amplification quality. The reactions were done using $30 \mathrm{ng}$ of DNA; $0.5 \mu \mathrm{M}$ of the primer; $1 \mathrm{U}$ of Taq DNA Polymerase; $0.3 \mathrm{mM}$ of dNTP; $1.5 \mathrm{mM}$ of magnesium chloride and $10 \%$ PCR buffer (1X - Phoneutria), with ultrapure water being added to complete $20 \mu \mathrm{L}$ reaction volume. The amplification conditions were: 5 minutes at 94 ${ }^{\circ} \mathrm{C}$; followed by 40 cycles for 1 minute at $94{ }^{\circ} \mathrm{C}$; 1 minute at $50{ }^{\circ} \mathrm{C}$ and 2 minutes at $72{ }^{\circ} \mathrm{C}$, with an extension of 10 minutes at $72{ }^{\circ} \mathrm{C}$. The fragments were separated by $1.5 \%$ agarose gel electrophoresis, stained with GelRed and $1 \mathrm{X}$ TBE runner at 90 volts for approximately 1.5 hours. The gels were photographed with ultraviolet light using the Photodocumentation System. All amplifications were performed in a Thermal Cycler (Veriti 384-well Thermal Cycler Applied Biosystems).

\section{Diversity analysis}

After the microsatellite alleles genotyping, the descriptive parameters of the locus were estimated by the expected heterozygosity (He), polymorphic information content (PIC), allele number in the population (AN), maximum allele frequency $(\mathrm{mf})$, number of alleles per locus $(\mathrm{Nm})$, total number of alleles $(\mathrm{Tn})$, allele proportion in each population (Ap) and rare allele number (Nr). Estimates of genetic diversity in the population were obtained according to the weighted index and UPGMA cluster analysis (Unweighted Pair Group Method Using Arithmethic Average).

In the analysis, using the ISSR data, the polymorphic bands in the individuals were coded as the presence of bands (1) and absence (0). Only bands presenting consistent amplification were considered. Estimates of genetic dissimilarity were performed according to Jaccarde, and UPGMA clustering was done. The difference between and within the populations was evaluated by molecular variance analysis AMOVA. All analyzes of genetic difference and clustering were performed with the aid of the Genes program (Cruz, 2016).

\section{Conclusion}

The $P$. Alata Curtis species was more divergent in relation to $P$. edulis Sims f. flavicarpa Deg. and P. edulis Sims. SSR and ISSR markers make it possible to indicate dissimilarity between species, but they did not always show variation results between and within similar species. The populations in low altitude are different from the others, independent of the species and the marker used.

\section{Acknowledgements}

FAPES (Fundação de Amparo à Pesquisa e Inovação do Espirito Santo) for granting a doctorate scholarship to the first author, CAPES (Coordenação de Aperfeiçoamento de Pessoal de Nível Superior) for granting a master's degree for the second and third authors and CNPq (Conselho Nacional de Desenvolvimento Científico e Tecnológico) for granting a scholarship for the penultimate and last authors. 


\section{References}

Barbara T, Palma-Silva C, Paggi GM, Bered F, Fay MF, Lexer C (2007) Cross-species transfer of nuclear microsatellite markers: potential and limitations. Mol Ecol. 16(18):37593767.

Bellon G, Faleiro FG, Junqueira KP, Junqueira NTV, Santos EC dos, Braga MF, Guimarães CT (2007) Variabilidade genética de acessos silvestres e comerciais de Passiflora edulis Sims. com base em marcadores RAPD. Rev Bras de Fruticul. 29(1):124-127.

Bernacci LC, Cervi AC, Giovanni R, Borges RAX, Hering RLO, Serrano T, Santos Filho LAF Passifloraceae. In: Martinelli G, Moraes MA (Org.) (2013) Livro vermelho da flora do Brasil. Rio de Janeiro: Instituto de Pesquisas Jardim Botânico do Rio de Janeiro, pp. 830-834.

Bernal-Parra N, Ocampo-Pérez J, Hernández-Fernández J (2014) Caracterizacion y analisis de la variabilidad genética de la granadilla (Passiflora ligularis Juss.) en Colombia empleando marcadores microsatélites. Rev Bras de Fruticult. 36(3):586-597.

Botstein D, White RL, Skolnick M, Davis RW (1980) Construction of a genetic linkage map in man using restriction fragment length polymorphisms. American $\mathrm{J}$ of Human Gen. 32(3):14-31.

Byars SG, Parsons Y, Hoffmann AA (2009) Effect of altitude on the genetic structure of an Alpine grass, Poa hiemata. Annals of Bot. 103(6):885-899.

Castro APG, Faleiro FG, Carvalho DDC, Fonseca KG, Vilela MF, Junqueira NTV, Cares JE (2011) Genetic variability of Passiflora spp. from commercial fields in the Federal District, Brazil. Ciênc Rural. 41(6):996-1002.

Castro JA, Oliveira EJ, Jesus ON, Soares TL, Margarido GRA (2016) Molecular markers for conservation genetic resources of four Passiflora species. Sci Hort. 212(1):251261.

Cazé ALR, Kriedt RA, Beheregaray LB, Bonatto SL, Freitas LB (2012) Isolation and characterization of microsatellite markers for Passiflora contracta. Int J of Mol Sci. 13(9):11343-11348.

Cerqueira-Silva CBM, Jesus ON, Santos ESL, Corrêa RX, Anete P, Souza AP (2014a) Genetic breeding and diversity of the genus Passiflora: progress and perspectives in molecular and genetic studies. Int J of Mol Scien. 5(8):14.122-14.152.

Cerqueira-Silva CBM, Santos ESL, Souza AM, Mori GM, Oliveira EJ, Corrêa RX, Souza AP (2012) Development and characterization of microsatellite markers for the wild South American Passiflora cincinnata (Passifloraceae). American J of Bot. 99(4): 170-172.

Cerqueira-Silva CBM, Santos ESL, Vieira JGP, Mori GM, Jesus ON, Corrêa RX, Souza AP (2014b) New microsatellite markers for wild and commercial species of Passiflora (Passifloraceae) and cross-amplification open access. Appli in Plant Scien. 2(2):1-5.

Costa JL, Jesus ON, Oliveira GAF, Oliveira EJ (2012) Effect of selection on genetic variability in yellow passion fruit. Crop Breed and Appl Biotechn. 12(4):253-260.

Cruz CD (2016) Genes Software - extended and integrated with the R, Matlab and Selegen. Acta Scien Agron. 38(4):547-552.

Doyle JJ, Doyle JL (1990) Isolation of plant DNA from fresh tissue. Focus. 12(1):13-15.

Fraife Filho GA, Leite JBV Ramos JV (2010) Maracujá.
Publicado no site da Comissão Executiva de Planejamento da Lavoura Cacaueira/CEPLAC. Disponível em:<http://www.ceplac.gov.br/radar/maracuja.htm>.

Acesso em: 15 jan. 2015.

Freitas JPX, Oliveira EJ, Cruz Neto AJ, Santos LR (2011) Avaliação de recursos genéticos de mudas de maracujazeiro-amarelo. Pesq Agrop Brasil. 46(9):10131020.

Gao L, Yang B (2006) Genetic diversity of wild Cymbidium goeringii (Orchidaceae) populations from Hubei based on ISSR analysis. Biod Scien. 14(3):250-257.

Hamrick JL, Godt MJW (1996) Effects of life history traits on genetic diversity in plant species. Philosoph Transact of the Royal Soc B-Bio Scien. 351(1345):1291-1298.

Hou Y, Lou A (2011) Population genetic diversity and structure of a naturally isolated plant species, Rhodiola dumulosa (Crassulaceae). Plos One. 6(9):e24497.

Hu Y, Xie X, Wang L, Zhang H, Yang J, Li Y (2014) Genetic variation in cultivated Rheum tanguticum populations. Gen and Mol Biol. 37(3):540-548.

Lougon CP, Viana AP, Santos EA, Freitas JC de O, Silva RNO, Oliveira EJ de (2014) Genetic variability assessment in the genus Passiflora by SSR markers. Chilean J of Agricul Res. 74(3):355-360.

Matioli SR (2001) Biologia Molecular e Evolução. Holos, Ribeirão Preto.

Melo CAF, Souza MM, Viana AP, Santos EA, Oliveira SV, Corrêa RX (2016) Morphological characterization and genetic parameter estimation in backcrossed progenies of Passiflora L. for ornamental use. Scien Horticult. 212(1):91103.

Missio RF, Teixera E, Zambolim EM, Zambolim L, Cruz CM, Sussumu N (2010) Polymorphic information content of SSR markers for Coffea spp. Crop Breed and Appl Biotechn. 10(1):89-94.

Ohsawa T, Ide Y (2008) Global patterns of genetic variation in plant species along vertical and horizontal gradients on mountains. Global Ecol and Biogeog. 17(2):152-163.

Ohsawa T, Tsuda Y, Saito Y, Sawada H, Ide Y (2007) Altitudinal genetic diversity and differentiation of Quercus crispula in the Chichibu Mountains, central Japan. Int J Plant Scien. 168(3):333-340.

Oliveira EJ, Pádua JG, Zucchi MI, Vencovsky R, Vieira MLC (2006) Origin, evolution and genome distribution of microsatellites. Genetics and Mol Bio. 29(2):294-307.

Pádua JG, Oliveira EJ, Zucchi MI, Oliveira GCX, Camargo LEA, Vieira MLC (2005) Isolation and characterization of microsatellite markers from the sweet passion fruit (Passiflora alata Curtis: Passifloraceae). Mol Ecol Not. 5(4):863-865.

Paiva CL, Viana AP, Santos EA, Freitas JCDO, Silva RNO, Oliveira EJD (2014) Genetic variability assessment in the genus Passiflora by SSR markers. Chilean J of Agricul Res. 74(3):355-360.

Pereira DA, Corrêa RX, Oliveira AC (2015) Molecular genetic diversity and differentiation of populations of 'somnus' passion fruit trees (Passiflora setacea DC): Implications for conservation and pre-breeding. Bioch Syst and Ecol. 59(1):12-21.

Pérez-Almeida I, Vásquez García S, Pérez D, Salazar E (2010) Genetic diversity in six species of Passiflora spp. using RAPD introducción. Rev Facul Agron. 27(3):347-359. 
Reis RV, Oliveira EJ, Viana AP, Pereira TNS, Pereira MG, Silva MGM (2011) Diversidade genética em seleção recorrente de maracujazeiro amarelo detectada por marcadores microssatélites. Pesq Agropec Bras. 46(1):51-57.

Santos LF, Oliveira EJ, Silva AS, Carvalho FM, Costa JL, Pádua, JG (2011) ISSR Markers as a tool for the assessment of genetic diversity in Passiflora. Bioch Gen. 49(7):540-554.
Vieira MLC, Santini L, Diniz AL, Munhoz CDF (2016) Microsatellite markers: what they mean and why they are so useful. Genetics and Mol Biol. 39(3):312-328. 